\title{
Drivers of ecosystem vulnerability to Corbicula invasions in southeastern North America
}

\author{
Noé Ferreira-Rodríguez $\mathbb{D} \cdot$ Michael Gangloff $\mathbb{}[$. \\ Gregory Shafer ${ }^{\circ} \cdot$ Carla L. Atkinson $(1)$
}

Received: 3 November 2020 / Accepted: 27 January 2022 / Published online: 14 February 2022

(C) The Author(s) 2022

\begin{abstract}
Invasive species introduction is one of the major ongoing ecological global crises. Identifying factors responsible for the success of invasive species is key for the implementation of effective management actions. The invasive filter-feeding bivalve, Corbicula, is of particular interest because it has become ubiquitous in many river basins across North America and elsewhere. Here we sampled bivalve assemblages, environmental indicators, and land cover parameters in the Ouachita highlands in southeastern Oklahoma and southwestern Arkansas, and in the Gulf Coastal Plain of Alabama to test three working models (using structural equation modeling, SEM) based on a priori scientific knowledge regarding Corbicula invasions. Our models tested three competing hypotheses: (1) Native mussel declines are related to land use changes
\end{abstract}

\footnotetext{
N. Ferreira-Rodríguez $(\bowtie)$

Departamento de Ecoloxía e Bioloxía Animal, Facultade de Bioloxía, Universidade de Vigo, Campus As Lagoas Marcosende, 36310 Vigo, Spain

e-mail: noeferreira@uvigo.es

M. Gangloff

Department of Biology, Appalachian State University,

Boone, NC, USA

G. Shafer

Department of Geography, University of Alabama, Tuscaloosa, AL, USA

C. L. Atkinson

Department of Biological Sciences, University

of Alabama, Tuscaloosa, AL, USA
}

at the watershed level and subsequent Corbicula colonization is a result of an empty niche; (2) Corbicula abundance is one of the factors responsible for native mussel declines and has an interactive effect with land use change at the watershed level; (3) Native mussel declines and Corbicula success are both related to land use changes at the watershed level. We found no evidence for the first two hypotheses. However, we found that environmental indicators and land cover parameters at the watershed scale were robust predictors of Corbicula abundance. In particular, agricultural land cover was positively related with Corbicula density. These results suggest that further improvement of conventional agricultural practices including the optimization of fertilizer delivery systems may represent an opportunity to manage this species by limiting nutrient inputs to stream ecosystems. Preservation of extensive floodplain habitats may help buffer these inputs by providing key ecosystem services including sediment and nutrient retention.

Keywords Invasive species - Freshwater mussels · Co-occurrence $\cdot$ Ecosystem resistance $\cdot$ Land cover . Managements $\cdot$ Impact adaptation

\section{Introduction}

One of the major goals of ecologists is to understand the distribution patterns of organisms and their underlying mechanisms. Additionally, researchers are 
trying to understand the factors that determine the ability of species to become invasive in novel ecosystems (McMahon 2002; Olsson et al. 2009), the habitats that are conducive to invasion (Havel et al. 2005), and how changes to habitats may influence the success of invasive species (Dukes and Mooney 1999; Weitere et al. 2009). Invasive species are widely accepted as one of the leading direct causes of biodiversity loss (Pimentel et al. 2005) and their establishment may lead to substantial changes in ecosystem function and structure (Crowl et al. 2008). For instance, invasive species can affect ecosystem processes through their resource acquisition, by altering disturbance regimes, or by altering trophic structure and/or food webs of the invaded system (Vitousek 1990).

In freshwater environments, Pearly mussels (Bivalvia; Unionoida, hereafter native mussels) are speciesrich and under natural and undisturbed conditions, may represent the major component of the benthic biomass in some systems (Strayer et al. 1999). The first extinctions of native mussels were recorded in the 1970s (Stansbery 1971). Since then, widespread declines in native mussel species have been documented in North America and elsewhere (Williams et al. 1993; Haag 2012; Lopes-Lima et al. 2017). The major causes of this decline are suspected to be a result of the cumulative, long-term effects of dams, land cover modification, and invasive species introductions (Bogan 1993; Haag 2009; FerreiraRodríguez and Pardo 2017). For instance, habitat loss, alteration, and fragmentation of river networks by dam construction are the most highly-cited causes of decline in the literature (Bogan 2008; Downing et al. 2010). In addition, land cover modification has been signaled as one of the major contributors to this decline because of increased nutrient loads and water pollution (Poole and Downing 2004). Interactions between these and other factors may account for the decline of mussel populations across broad spatial scales and may have, in turn, led to biologically depauperate environments easily colonized by invasive species in many freshwater ecosystems (Mills et al. 1993; Johnson and Carlton 1996).

In this study we focus on the Asian clam, genus Corbicula Megerle von Mühlfeld, 1811, an invasive bivalve that can be found at very high densities in North America. The taxonomy of Corbicula is uncertain and species determination is difficult because of morphological plasticity/variability (Lee et al. 2005; Sousa et al. 2008; Pigneur et al. 2011). The most recent study to examine this question in North America (Haponski and Ó Foighil 2019) revealed evidence of multiple clonal lineages but did not find evidence for multiple taxa. Hence, we will follow Araujo et al. (2020) and refer to North American Corbicula fluminea sensu lato (hereafter Corbicula) throughout this manuscript. Corbicula was probably introduced to North America (West Coast) in the early 1920s. Over the next five decades, the species dispersed to nearly every major watershed in the continent (see McMahon (1982) for a detailed description of Corbicula early spread). Although the precise invasion history of Corbicula in North America is unknown, evidence suggests that it was concomitant with freshwater mussel declines in many systems. It is commonly assumed that invasive species impact indigenous species and promote their decline through direct competition for space, nutrients or food resources (Dextrase and Mandrak 2006; Hermoso et al. 2011). However, it is not clear whether Corbicula introductions have contributed to native mussel declines or whether native mussel declines aided Corbicula invasions by the creation of empty niche space.

The habitat use, feeding mechanisms and behaviors of Corbicula are similar to those of native mussels. Corbicula burrow in the sediment, filter-feed on suspended matter, and often occur in dense $(>500$ ind. $/ \mathrm{m}^{2}$ ) aggregations in stable substrates (Hakenkamp et al. 2001). There is continued debate about whether native mussels and Corbicula compete for space and food, and whether Corbicula may be displacing natives via competition or other mechanisms (Strayer 1999; Vaughn and Spooner 2006; Atkinson et al. 2011; Ferreira-Rodríguez et al. 2018a, b; Haag et al. 2021). However, it is possible that the decline of native mussels may also be one of the primary mechanisms contributing to the spread of Corbicula, but few prior studies have examined this hypothesis across broad spatial scales (i.e., across multiple drainages and physiographic provinces).

Invasive species theory predicts that diverse communities of native species should confer some degree of ecosystem resistance against invasions (MacArthur 1955; D'Antonio et al. 2001), but other research has also refuted this theory (Holle and Simberloff 2005). Diverse and abundant native mussel faunas may provide ecosystem resistance to Corbicula invasions 
as a function of their level of mass-specific filtering capacity, their occurrence in high-density, multi-species mussel-beds and their adaptation to local environments [i.e., Elton's (1958) Ecological Resistance Hypothesis; Simberloff 2011]. Vaughn and Spooner first provided observational evidence supporting this theory in 2006. They found that in streams with intact native mussel aggregations, Corbicula density was never high in patches where mussels were dense. In contrast, in degraded environments, invasive species may be more successful than more ecologically-sensitive native species (Ruaro et al. 2018). This is perhaps because native species and communities may more effectively use resources (i.e., niche partitioning; Eisenhauer et al. 2013; Byun et al. 2018) in lessimpacted habitats, resulting in fewer resources available to invasive species. However, resource availability may co-vary with underlying environmental conditions resulting from changing land cover (Levine and D’Antonio 1999).

There are different mechanisms that may determine Corbicula success and we aimed to evaluate three competing hypotheses (Fig. 1) by examining both indirect and direct causal relationships between abiotic factors, land use, habitat alteration, Corbicula density and freshwater mussel diversity. We specifically examined whether: (1) native mussel declines are related to changes at the watershed level (i.e., hydromorphological alterations and land cover) and Corbicula colonization is facilitated by the creation of empty niches; (2) Corbicula colonization is, together with changes at the watershed level, one of the factors responsible for native mussel declines; or (3) native mussels declined for unknown reasons and, together with subsequent changes at the watershed level, their decline is one of the factors responsible for Corbicula success. This information may help inform management actions (e.g., habitat restoration and/or native mussel re-introductions) intended to mitigate the impact of Corbicula invasions.

\section{Material and methods}

Study areas

We examined associations between Corbicula and native mussels in two distinct biogeographic regions of North America; the Ouachita Highlands in southeastern Oklahoma and southwestern Arkansas, and the Gulf Coastal Plain of west-central Alabama (Fig. 2). These two regions support diverse

\section{Model 1: Empty niche}

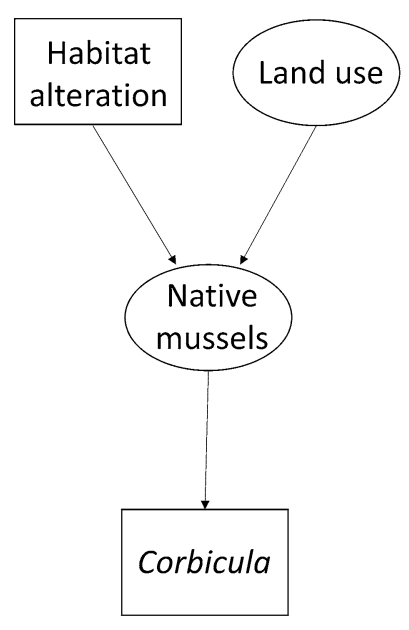

Model 2: Competition

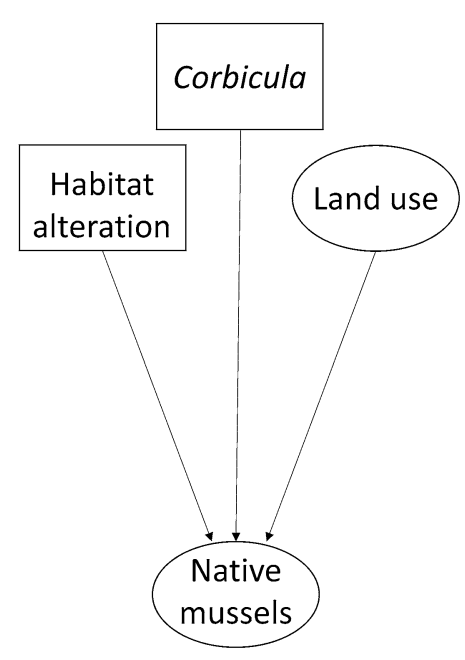

Model 3: Ecological resistance

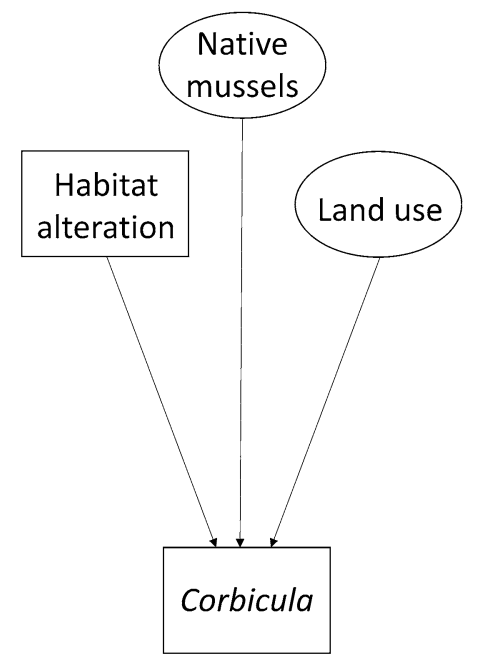

Measured variable Latent variable

Fig. 1 Models tested in the SEM analysis. Three models were designed to explain Corbicula success based on empty niche creation (Model 1), competition theory (Model 2), and the ecological resistance hypothesis (Model 3) 


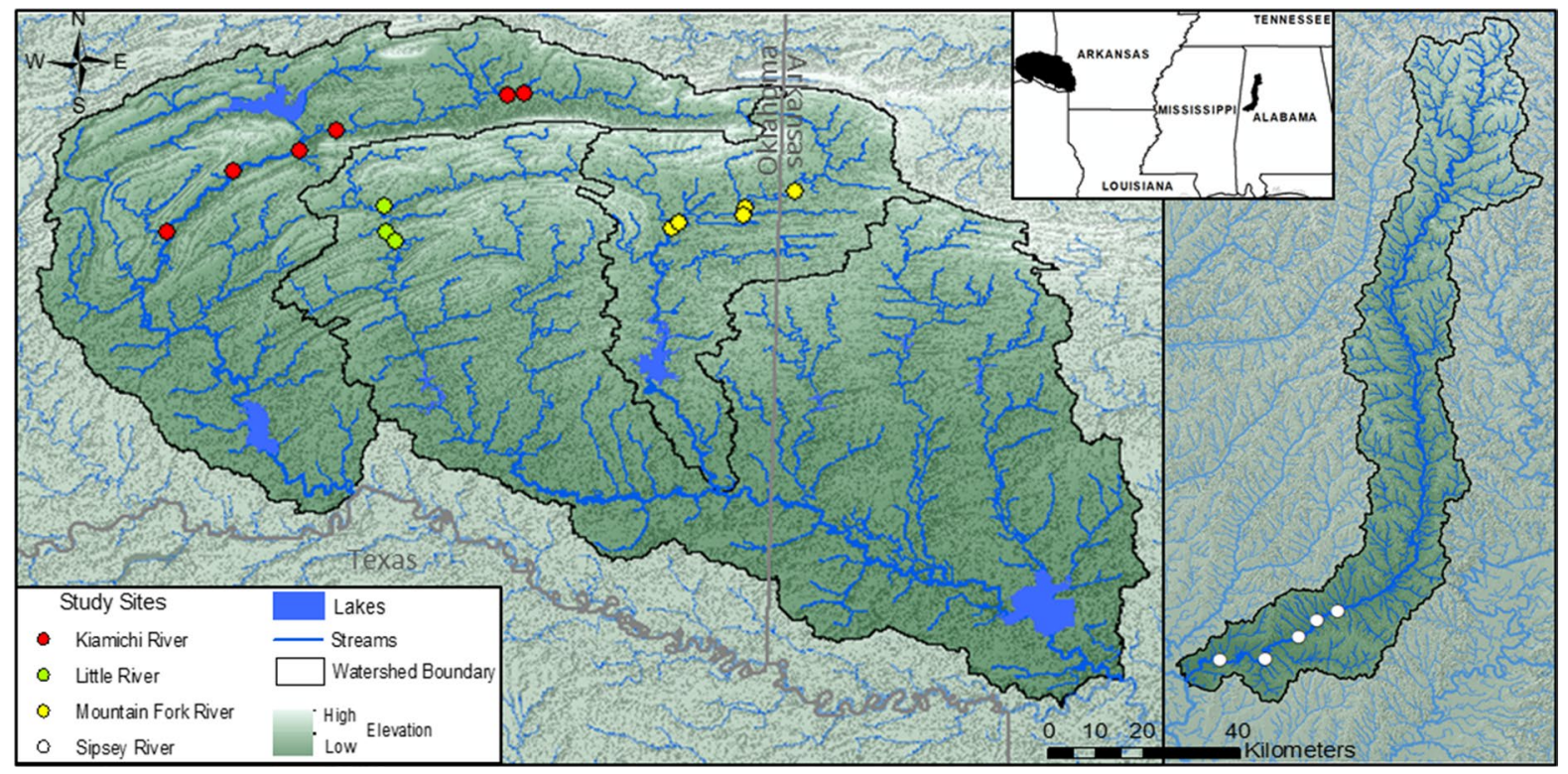

Fig. 2 Sampling locations, streams and man-made lakes (dams) in Oklahoma (Kiamichi, Little, and Mountain Fork Rivers; Red River watershed) and Alabama (Sipsey River; Tombigbee River watershed). Green color gradient shows elevation

and endemic native freshwater mussel assemblages $(40+$ extant species in each region) with relatively few species in common (Haag 2009, 2012). In the Ouachita Highlands, three rivers (Kiamichi, Little, and Mountain Fork rivers; Red River watershed) were surveyed in 2012. In the Gulf Coastal Plain, the Sipsey River (Tombigbee River watershed) was surveyed in 2016.

All three focal rivers in the Red River Watershed are blocked by major dams constructed in 1969 (Pine Creek Lake, Little River), 1970 (Broken Bow Lake, Mountain Fork River) and 1974 (Hugo Lake, Kiamichi River). In addition, three sampling points at the Kiamichi River are downstream from an impoundment, Sardis Lake (Fig. 2). This reservoir, constructed between 1977 and 1982, may affect downstream water quality in terms of flow and thermal conditions and other environmental factors (Kędra and Wiejaczka 2018; and references therein). There are no major impoundments on the Sipsey River. However, fish and mollusk migration is impeded downstream in the Tombigbee River by two dam complexes constructed in 1954 (Demopolis Lock and Dam) and 1972 (Howell Heflin Lock and Dam).

\section{Sampling strategy}

In the Ouachita Highlands, 15 sites across the 3 rivers were selected. Each site was subdivided into three reaches and, in each reach, one 100-m transect was selected. In the Gulf Coastal Plain, 6 sites in the Sipsey River were selected. Each site was subdivided into three reaches, and each reach into twelve $80-\mathrm{m}$ transects. In order to characterize bivalve abundance and assemblage composition we followed the methodology proposed by Villella and Smith (2005). This method relies on a two-phase sampling design that yields precise estimates of mussel densities and does not require further efforts to determine when all species present are detected. First, qualitative samples (one 30-min timed visual/tactile search per reach) were done to locate mussel beds and to establish native mussel species composition. Second, between five and eighteen $0.25 \mathrm{~m}^{2}$ quadrats-including cobble, sand and muddy sediments-were excavated (to a depth of $\sim 10 \mathrm{~cm}$ ) and sieved (through $6 \mathrm{~mm}$ mesh) in each transect. Richness (number of taxa) and density (number ind. $/ \mathrm{m}^{2}$ ) were computed by species at the quadrat scale. 
Physicochemical parameters

Temperature, $\mathrm{pH}$, conductivity $(\mu \mathrm{S} / \mathrm{cm})$, and dissolved oxygen $(\mathrm{mg} / \mathrm{L})$ were measured with a DO meter (accuracy $\pm 0.2-0.3 \mathrm{mg} / \mathrm{L}$, resolution $0.01 \mathrm{mg} / \mathrm{L}$ ) and a conductivity- $\mathrm{pH}$ meter $(\mathrm{pH}$ accuracy $\pm 0.1-0.2$, resolution 0.01 unit; conductivity accuracy $\pm 0.5 \mu \mathrm{S} /$ $\mathrm{cm}$, resolution $01-1 \mu \mathrm{S} / \mathrm{cm})$. Also, samples for total dissolved nitrogen and phosphorus were collected, field-filtered, acidified, and analyzed (following persulfate digestion) within 28 days of collection using a flow injection analyzer. All habitat variables were measured under summer or fall base flow conditions, typically during or immediately following mussel surveys.

\section{Land cover parameters}

We used ArcGIS (Version 10.0, ESRI, Redlands, California) to obtain landscape-scale habitat and land cover classification data at the 21 sites at a spatial resolution of $30 \mathrm{~m}$. We measured upstream catchment area $\left(\mathrm{km}^{2}\right)$, rank and link magnitude (the number of upstream first order tributaries) and percentage of surface cover comprising 11 land cover classes (open water, wetland, high-intensity urban, low-intensity urban, grassland, pasture, row-crop agriculture, evergreen, deciduous and mixed forest, and barren ground). Based on a priori scientific knowledge, our objective was to assess the effect of land cover rather than the effects of different vegetation classes. Hence, we combined several land cover classes to compute coarse scale land cover parameters. Specifically, we combined the percentage of open water and wetland classes into water; high-intensity and low-intensity urban into urban; pasture, row-crop agriculture, grassland into agriculture; and deciduous, evergreen, and mixed forest into forest. Finally, following Allen et al. (2018) we identified study sites located downstream of dams and calculated the potential influence of a dam on that site as the height of the dam divided by the distance a site is downstream of the dam.

\section{Statistical analysis}

We used a structural equation modeling (SEM) approach to assess whether the data support any of the three working models (Fig. 1) developed based on a priori scientific knowledge. In SEM, there is no requirement for predictor variables to be parametric. However, because dependent variables did not fit a multivariate normal distribution (Shapiro-Wilks test, $P<0.001$ ), the robust Satorra and Bentler (2001) method was applied to adjust for deviation from normality. Because the Satorra and Bentler method is only valid for matrices with no missing data, a final matrix of 333 quadrats covering 16 sites with complete information (i.e., physicochemical and land cover information) was used. Data were clustered to test our working hypotheses at the individual watershed, river and site scale.

Three latent factors (i.e., biodiversity, abiotic factors, and land use) were calculated. First, because the number of species, as well as the number of individuals of each species, are common constituents of diversity indexes, biodiversity, as latent factor, was measured by two observed factors: native mussel richness and total native mussel density. Second, temperature, water $\mathrm{pH}$, conductivity, $\mathrm{DO}$ and total $\mathrm{N}$ were combined as abiotic factors. In addition, covariance between temperature and DO and between DO and total $\mathrm{N}$ was modeled. Third, anthropogenic land uses (i.e., urban and agriculture cover) were combined as land use. Finally, because SEMs can handle both single-indicator and latent (i.e., multiple-indicator) factors, habitat alteration, as measured by the potential influence of (i.e., distance to) a dam, was included in the model. Links between native mussel diversity and Corbicula density were investigated throughout three paths. In the first (Empty Niche) model, abiotic factors, land use and habitat alteration influence native mussel diversity, and diversity can predict Corbicula density. In the second (Competition) model, abiotic factors, land use, habitat alteration and Corbicula density influence native mussel diversity. In the third (Ecological Resistance) model, abiotic factors, land use, habitat alteration and native mussel diversity predict Corbicula density.

Based on Hu and Bentler's (1999) Two-Index Presentation Strategy for evaluating model fit, we used the standardized root mean squared residual (SRMR) as an absolute fit index, and the Comparative Fit Index (CFI) as an incremental fit index. Both are robust to violations of normality and are useful for small sample sizes (Hu and Bentler 1999). The SRMR should be $\leq 0.08$ and the minimum value for CFI should be $\sim 0.9$ to indicate adequate fit of the model to the data. The model needs to meet both SRMR and CFI 
cutoff criteria to be considered acceptable. All SEMs were evaluated using the lavaan package (version 0.5-22; Rosseel 2012) in $\mathrm{R}$ (version 3.3.1, R Core Team 2018).

\section{Results}

We collected 8490 freshwater mussels in 1073 quadrats from 20 of the 21 sites in four rivers within the two river basins. Pooling all collections, at the quadrat scale, mussel density ranged from 0 to 448 ind./ $\mathrm{m}^{2}$ (mean \pm SE: $31.65 \pm 1.37$ ind. $/ \mathrm{m}^{2}$ ). Quadrat-level species richness ranged from 0 to 11 (mean $\pm \mathrm{SE}$ : $2.67 \pm 0.07 \mathrm{spp} . / \mathrm{m}^{2}$ ), with the greatest density and richness occurring in the Sipsey River. In total, 4126 individuals of Corbicula were collected. Corbicula density ranged from 0 to 348 ind. $/ \mathrm{m}^{2}$ (mean \pm SE: $15.38 \pm 1.07 \mathrm{ind} . / \mathrm{m}^{2}$ ), with the greatest density occurring in the Mountain Fork River (Fig. 3).

We checked alternative models at different scales (results not shown), but model support was strongest clustering the data at the individual watershed (hydrologic unit code: HUC-8; available at https://water. usgs.gov/GIS/huc.html) scale. Based on the cutoff criteria for SRMR $(<0.08)$ and CFI $(>0.9)$ indexes, only the third model met both criteria of acceptability (i.e., Ecological Resistance Model; SRMR $=0.049$, CFI =1.000; Table 1). In contrast, the Empty Niche Model and the Competition Model met the CFI cutoff criterion but did not meet the SRMR cutoff criterion $(\mathrm{SRMR}=0.106$ and $\mathrm{CFI}=1.000$, and $\mathrm{SRMR}=0.118$ and $\mathrm{CFI}=0.985$, respectively).

Abiotic factors and land use had significant regression weights in the Ecological Resistance Model
Fig. 3 Patterns of native mussel a density (number ind. $/ \mathrm{m}^{2}$ ) and $\mathrm{b}$ richness (number of taxa), and c Corbicula density (number ind. $/ \mathrm{m}^{2}$ ) by river. The boxes indicate the 1st and 3rd quartiles, and the dark lines indicate the median. Points more than 1.5 times the inter-quartile range away from the box are shown with hollow circles
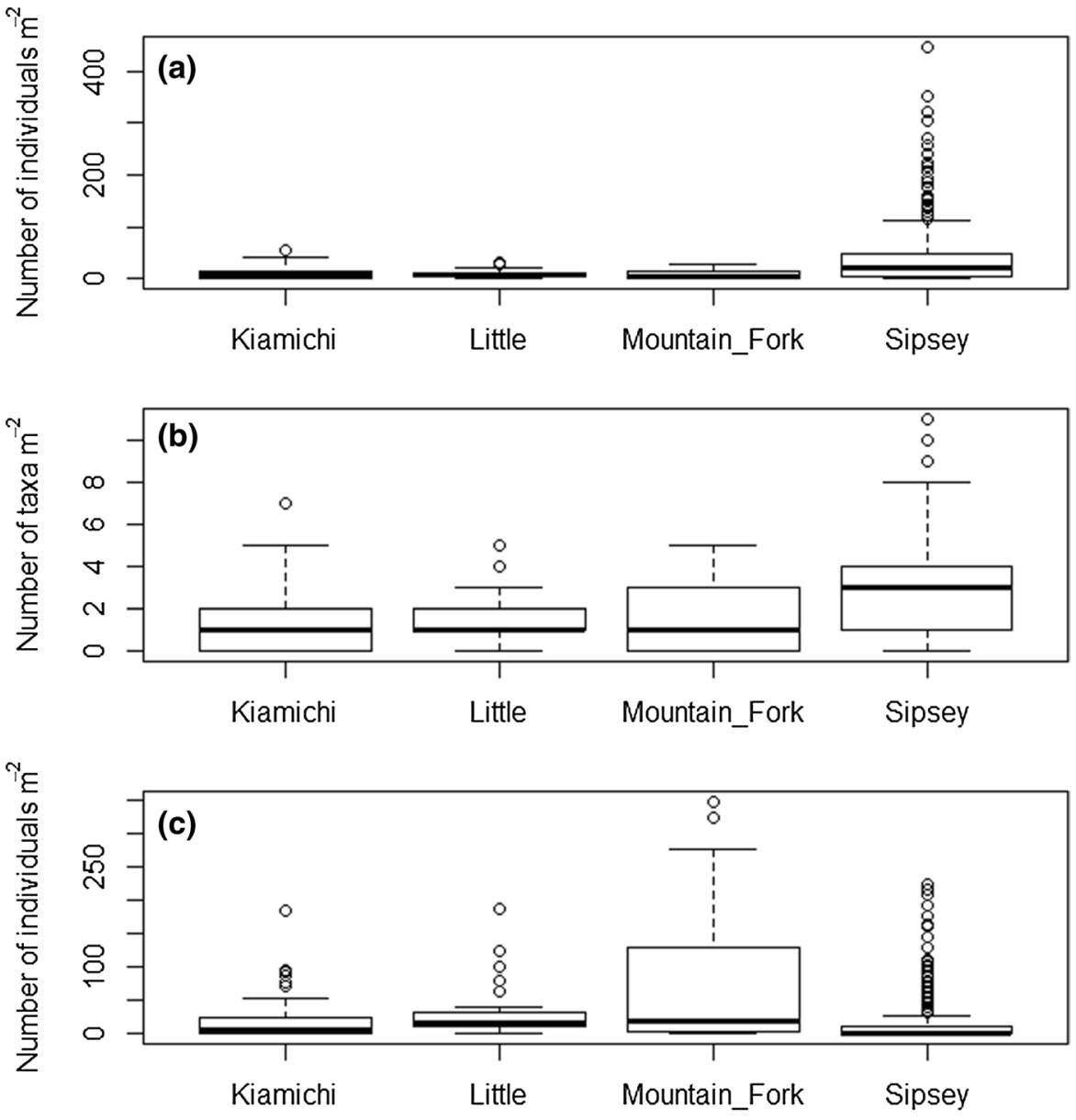

River 
Table 1 Model fits for the three suggested pathways explaining native mussel decline and Corbicula success in southern North America. The cutoff criteria were set as $<0.08$ for mean squared residual (SRMR) and as $>0.9$ for the Comparative Fit Index (CFI)

\begin{tabular}{|c|c|c|c|c|c|}
\hline Model & Definition & Dependent & Explanatory & SRMR & CFI \\
\hline 1 & Empty niche & Corbicula & Biodiversity & 0.106 & 1 \\
\hline 2 & Competition & Biodiversity* & $\begin{array}{l}\text { Abiotic factors, Land Use, } \\
\text { Habitat alteration, Cor- } \\
\text { bicula }\end{array}$ & 0.118 & 0.985 \\
\hline 3 & Ecological resistance & Corbicula & $\begin{array}{l}\text { Abiotic factors, Land Use, } \\
\text { Habitat alteration, Biodi- } \\
\text { versity }\end{array}$ & 0.049 & 1 \\
\hline
\end{tabular}

*Biodiversity: latent factor measured by native mussel richness and total native mussels' density

$(p<0.05)$. Urban land cover was negatively related to land use (path weight $=-0.52$ ) whereas agriculture land cover was positively related to land use (path weight $=4.44$ ), suggesting an indirect positive effect of agriculture cover on Corbicula density. Abiotic factors were related with temperature (path weight $=0.121), \mathrm{pH} \quad($ path weight $=0.228)$, conductivity (path weight $=-0.599$ ), DO (path weight $=0.053$ ) and total $\mathrm{N}$ (path weight $=0.674$ ). In addition, total $\mathrm{N}$ had a negative relationship with DO (path weight $=-0.03$ ). However, neither native mussel diversity nor habitat alteration were statistically significant predictors of Corbicula density $(p<0.05)$ (Table 2).

\section{Discussion}

We examined the direct and indirect causal relationships between abiotic factors, land use, habitat alteration, Corbicula density and native mussel diversity. Specifically, we examined the likelihood of three scenarios: (1) Native mussel declines were related to land use changes at the watershed level and subsequent Corbicula colonization was a result of an empty niche. (2) Corbicula abundance is one of the factors responsible for native mussel declines. (3) Corbicula invasions act in concert with land use change to drive native mussel declines at the watershed level. Our results show that Corbicula density was partially explained by a sub-set of commonly measured land cover and stream physicochemical parameters. In particular, Corbicula density at the watershed scale was positively related to agricultural land cover and negatively related to urban land cover. Similarly, Corbicula density was negatively related to abiotic factors, which were characterized by higher temperatures, $\mathrm{pH}$, DO, total $\mathrm{N}$ and lower conductivity levels. Among our environmental indicators, total $\mathrm{N}$-which most strongly links abiotic factors to agricultural land cover-is an important latent indicator of Corbicula density. Understanding how these land use and habitat conditions synergistically interact to explain Corbicula density and distribution at the local and watershed scale, may be important for managing Corbicula invasions. It should be noted, however, that all habitat variables were measured under summer or fall base flow conditions, which may not account for seasonal differences. Despite this, measuring water chemistry parameters under summer or early fall base flow conditions in this region may provide the best measure of conditions that may limit the distribution or population size of native and invasive bivalves.

Environmental parameters have been previously linked with Corbicula density at different organizational levels, ranging from internal metabolic
Table 2 Regression statistics produced from the SEM analysis

\begin{tabular}{lllllll}
\hline Latent Factor & Indicator & $\mathrm{B}$ & $\mathrm{SE}$ & $\mathrm{Z}$ & $\mathrm{p}$-value & Beta \\
\hline Corbicula & Abiotic factors & -15.951 & 1.009 & -15.817 & 0.000 & -0.358 \\
Corbicula & Land Use & 38.086 & 9.927 & 3.837 & 0.000 & 0.856 \\
Corbicula & Habitat alteration & -7.222 & 4.441 & -1.626 & 0.104 & -0.162 \\
Corbicula & Biodiversity & 3.904 & 5.950 & 0.656 & 0.512 & 0.088 \\
\hline
\end{tabular}


processes to population dynamics (Vidal et al. 2002; Sousa et al. 2008; Ferreira-Rodríguez and Pardo 2014). For instance, temperature may be related to extreme climatic events that have drastically reduced Corbicula population densities in invaded regions globally (Werner and Rothhaupt 2008; Ilarri et al. 2011; McDowell et al. 2017). Stream pH appears to influence the vulnerability of Corbicula to other ecological stressors as changes to stream acidity affect the ability of bivalves to detoxify metabolic wastes and increases their sensitivity to chemical pollutants from urban and industrial activities (Vidal et al. 2002; Fournier et al. 2004). Conversely, increased concentrations of dissolved ions including $\mathrm{Ca}^{2+}(\mathrm{a}$ key component of bivalve shells and metabolic processes) buffer many fresh waters in this region against acidification but high-conductivity waters also support higher Corbicula density and population growth rates (Ferreira-Rodríguez et al. 2017). The negative relationships observed between Corbicula density and DO may be related to the ability of Corbicula to modify local physicochemical conditions through organic matter accumulation and decomposition, or to DO directly controlling Corbicula populations (Hakenkamp and Palmer 1999; Ferreira-Rodríguez et al. 2019).

Environmental conditions have changed in North American fresh waters since the establishment of the first human settlements in pre-colonial times (Stinchcomb et al. 2011). Nevertheless, it was in colonial and pre-industrial times that intensive land use change (e.g., forest clearing, plowing, and mining; James 2011) had the most profound influence on hydrological systems. Between 1850 and 1950, thanks to improved mechanization, synthetic fertilizers, and improved varieties of seed, agricultural development greatly expanded spatially and dramatically increased total crop yields and the productivity of land under cultivation (USDA 2012). Watershed denudation following the loss of native forest cover and its subsequent conversion into agricultural or timber lands has reduced water retention capacity, increasing runoff, erosion, and sediment load across much of eastern and southeastern North America (Troendle and Olsen 1994; Zhang et al. 2017). In addition, much of North America experienced a substantial increase in the use of nitrogen fertilizers linked to agriculture during the twentieth century (Power and Schepers 1989). In both ground and surface waters, chronic nutrient enrichment after decades of intensive fertilization has altered stream productivity and energetic pathways, and has had dramatic effects on aquatic biota (David et al. 2010; Pascal et al. 2013; Stelzer et al. 2020). Increased stream productivity associated with agricultural enrichment may be especially relevant for Corbicula as these bivalves apparently require a high quantity of food resources during the exponential phase of population growth and range expansion (Burke and Grime 1996; Petter et al. 2014). In this sense, the relationships between Corbicula and agricultural land cover found within our model may at least partially explain its successful establishment in most temperate and subtropical North American watersheds. However, in the second half of the $20^{\text {th }}$ Century, total land devoted to agricultural production decreased, leading to a drastic reduction in total nitrogen and phosphorous loads (David et al. 2010; and references therein). Hence, it is possible that these changes may have to some degree moderated Corbicula productivity and standing crops across its naturalized range in North America. Unfortunately, Corbicula densities are rarely quantified by biologists in long term monitoring programs so it is difficult to assess changes in abundance or even occupancy (Sanchez Gonzalez et al. 2021).

Although environmental conditions may have improved in recent decades, Corbicula has already become widely established across North America. As a result, complete eradication is unlikely to be feasible. However, there are a few management options that may help reduce Corbicula productivity (sensu Robertson et al. 2020). First, monitoring environmental conditions in order to assess the role of habitat suitability (e.g., warm streams with high $\mathrm{N}$ and DO levels) and using models of land use and water chemistry to predict which habitats can support the establishment of large populations of Corbicula may help reduce the size and productivity of potential sources of further invasion. In regulated streams it may be possible to alter some environmental parameters and create conditions that are unfavorable to Corbicula (e.g., manipulate water temperatures or oxygen concentrations that are beyond the tolerances of Corbicula but not native bivalves) and reduce population size. Second, further improvement of conventional agricultural practices through upland and riparian zone forest protection along with use of precision farming at the watershed scale and the 
implementation of more efficient fertilizer delivery systems could help reduce nutrient levels in surface and groundwaters (sensu Diacono et al. 2013). Ultimately, broad-scale efforts to reduce nutrient loading and in-stream productivity appear to have the greatest potential to limit the further establishment of dense Corbicula populations while probably also benefitting native bivalve faunas.

\section{Conclusion}

The success of Corbicula across North American watersheds appears to be explained partially by the extent of in-stream nutrient enrichment and food availability linked to agricultural development. Hence, we suggest that implementing invasive species management practices at the watershed scale and focusing on both aquatic and terrestrial environments is critical. In particular, we suggest that nutrient management is needed to reduce riverine nutrient inputs. This causal link requires further investigation, but could represent the basis for designing management plans aimed to limit the spread and productivity of Corbicula. Although our model is robust, we cannot exclude the possibility that observed Corbicula densities may be related to other sources of habitat degradation not considered in this study. Our results may help invasive species managers achieve successful outcomes while minimizing costs and impacts to sensitive native biota, including native mussels. It remains difficult, however, to draw conclusions from observational data about causal links between Corbicula invasions and the decline of native mussels in North America. In this regard, manipulative experiments are needed to explore further how changes related to agricultural development may affect competition.

Acknowledgements This manuscript was designed while NF-R was on a research stay at the Oklahoma Biological Survey, Norman, Oklahoma, USA. NF-R was supported by a postdoctoral fellowship (Xunta de Galicia Plan I2C 2017-2020, 09.40.561B.444.0) from the government of the autonomous community of Galicia. CLA was supported by the Alabama Department of Natural Resources and Conservation and the National Science Foundation DEB-1831512 provided support for this project. Freshwater mussel collection in Alabama was conducted under ALCDNR permit \# 2016077745468680. We thank the editor and three anonymous reviewers for their constructive comments.

Authors' contribution CA and MG conceived and planned the field work. CA and MG carried out the field sampling. CA and GS performed the GIS analysis. NF-R designed the models and analysed the data. NF-R. wrote the manuscript in consultation with CA over the original idea from CA and MG. All authors provided critical feedback and contributed to the final version of the manuscript.

Funding Open Access funding provided thanks to the CRUE-CSIC agreement with Springer Nature. Funding for open access charge: Universidade de Vigo/CISUG

\section{Declarations}

Conflict of interest The authors declare no conficts of interest or competing interests.

Open Access This article is licensed under a Creative Commons Attribution 4.0 International License, which permits use, sharing, adaptation, distribution and reproduction in any medium or format, as long as you give appropriate credit to the original author(s) and the source, provide a link to the Creative Commons licence, and indicate if changes were made. The images or other third party material in this article are included in the article's Creative Commons licence, unless indicated otherwise in a credit line to the material. If material is not included in the article's Creative Commons licence and your intended use is not permitted by statutory regulation or exceeds the permitted use, you will need to obtain permission directly from the copyright holder. To view a copy of this licence, visit http://creativecommons.org/licenses/by/4.0/.

\section{References}

Allen DC, Wynn-Thompson TM, Kopp DA, Cardinale BJ (2018) Riparian plant biodiversity reduces stream channel migration rates in three rivers in Michigan, USA. Ecohydrology 11:e1972. https://doi.org/10.1002/eco.1972

Araujo R, Moreno D, Machordom A (2020) Review of the invasive species Corbicula fluminea s.l. in Iberia with reference to two new cites in the provinces of Madrid and Almería. Iberus 38:113-133 ((IN Spanish))

Atkinson CL, First MR, Covich AP, Opsahl SP, Golladay SW (2011) Suspended material availability and filtration-biodeposition processes performed by a native and invasive bivalve species in streams. Hydrobiologia 667:191-204. https://doi.org/10.1007/s10750-011-0640-5

Bogan AE (1993) Freshwater bivalve extinctions (Mollusca: Unionoida): a search for causes. Am Zool 33:599-609. https://doi.org/10.1093/icb/33.6.599

Bogan AE (2008) Global diversity of freshwater mussels (Mollusca, Bivalvia) in freshwater. In: Balian EV, Lévêque C, Segers H, Martens K (eds) Freshwater Animal Diversity Assessment. Springer, Dordrecht 
Burke MJW, Grime JP (1996) An experimental study of plant community invasibility. Ecology 77:776-790. https://doi. org/10.2307/2265501

Byun C, de Blois S, Brisson J (2018) Management of invasive plants through ecological resistance. Biol Invas 20:13-27. https://doi.org/10.1007/s10530-017-1529-7

Crowl TA, Crist TO, Parmenter RR, Belovsky G, Lugo AE (2008) The spread of invasive species and infectious disease as drivers of ecosystem change. Front Ecol Environ 6:238-246. https://doi.org/10.1890/070151

D’Antonio C, Levine J, Thomsen M (2001) Ecosystem resistance to invasion and the role of propagule supply: a California perspective. J Mediterr Ecol 2:233-246

David MB, Drinkwater LE, McIsaac GF (2010) Sources of nitrate yields in the Mississippi River Basin Watershed. J Environ Qual 39:1657-1667. https://doi.org/10.2134/ jeq2010.0115

Dextrase AJ, Mandrak NE (2006) Impacts of alien invasive species on freshwater fauna at risk in Canada. Biol Invasions 8:13-24. https://doi.org/10.1007/s10530-005-0232-2

Diacono M, Rubino P, Montemurro F (2013) Precision nitrogen management of wheat. A Rev Agron Sustain Dev 33:219-241. https://doi.org/10.1007/s13593-012-0111-z

Downing JA, Van Meter P, Woolnough DA (2010) Suspects and evidence: a review of the causes of extirpation and decline in freshwater mussels. Anim Biodivers Conserv 33:151-185

Dukes JS, Mooney HA (1999) Does global change increase the success of biological invaders? Trends Ecol Evol 14:135139. https://doi.org/10.1016/S0169-5347(98)01554-7

Eisenhauer N, Schulz W, Scheu S, Jousset A (2013) Niche dimensionality links biodiversity and invasibility of microbial communities. Funct Ecol 27:282-288. https:// doi.org/10.1111/j.1365-2435.2012.02060.x

Elton CS (1958) The ecology of invasions by plants and animals. Methuen, London

Ferreira-Rodríguez N, Fandiño L, Pedreira A, Pardo I (2018a) First evidence of asymmetric competition between the non-native clam Corbicula fluminea and the native freshwater mussel Unio delphinus during a summer heat wave. Aquat Conserv 28:1105-1113. https://doi.org/10.1002/ aqc. 2964

Ferreira-Rodríguez N, Fernández I, Varandas S, Cortes R, Cancela ML, Pardo I (2017) The role of calcium concentration in the invasive capacity of Corbicula fluminea in crystalline watersheds. Sci Total Environ 580:1363-1370. https://doi.org/10.1016/j.scitotenv.2016.12.100

Ferreira-Rodríguez N, Iglesias J, Pardo I (2019) Corbicula fluminea affecting supporting ecosystem services through nutrient and biogenic matter incorporation in invaded estuaries. Fundam Appl Limnol 192:269-280. https://doi. org/10.1127/fal/2019/1132

Ferreira-Rodríguez N, Pardo I (2014) Abiotic controls on population structure of the invasive Corbicula fluminea (Müller, 1774) in the River Miño estuary. Fundam Appl Limnol 184(4):329-339. https://doi.org/10.1127/1863-9135/ 2014/0567

Ferreira-Rodríguez N, Pardo I (2017) The interactive effects of temperature, trophic status, and the presence of an exotic clam on the performance of a native freshwater mussel.
Hydrobiologia 797(1):171-182. https://doi.org/10.1007/ s10750-017-3170-y

Ferreira-Rodríguez N, Sousa R, Pardo I (2018b) Negative effects of Corbicula fluminea over native freshwater mussels. Hydrobiologia 810:85-95. https://doi.org/10.1007/ s10750-016-3059-1

Fournier E, Tran D, Denison F, Massabuau JC, GarnierLaplace J (2004) Valve closure response to uranium exposure for a freshwater bivalve (Corbicula fluminea): quantification of the influence of $\mathrm{pH}$. Environ Toxicol Chem 23:1108-1114. https://doi.org/10.1897/02-604

Haag WR (2009) Past and future patterns of freshwater mussel extinctions in North America during the Holocene. In: Turvey ST (ed) Holocene extinctions. Oxford University Press, Oxford, pp 107-128

Haag WR (2012) North American freshwater mussels: natural history, ecology, and conservation. Cambridge University Press, New York

Haag WR, Culp J, Drayer AN, McGregor MA, White DE, Price SJ (2021) Abundance of an invasive bivalve, Corbicula fluminea, is negatively related to growth of freshwater mussels in the wild. Freshw Biol 66:447-457. https://doi.org/10.1111/fwb.13651

Hakenkamp CC, Palmer MA (1999) Introduced bivalves in freshwater ecosystems: the impact of Corbicula on organic matter dynamics in a sandy stream. Oecologia 119:445-451. https://doi.org/10.1007/s004420050806

Hakenkamp CC, Ribblett SG, Palmer MA, Swan CM, Reid JW, Goodison MR (2001) The impact of an introduced bivalve (Corbicula fluminea) on the benthos of a sandy stream. Freshw Biol 46:491-501. https://doi.org/10.1046/j.13652427.2001.00700.x

Havel JE, Lee CE, Vander Zanden MJ (2005) Do reservoirs facilitate invasions into landscapes? Bioscience 55:518525. https://doi.org/10.1641/0006-3568(2005)055[0518: DRFIIL]2.0.CO;2

Hermoso V, Clavero M, Blanco-Garrido F, Prenda J (2011) Invasive species and habitat degradation in Iberian streams: an analysis of their role in freshwater fish diversity loss. Ecol Appl 21:175-188. https://doi.org/10.1890/ 09-2011.1

Holle BV, Simberloff D (2005) Ecological resistance to biological invasion overwhelmed by propagule pressure. Ecology 86:3212-3218. https://doi.org/10.1890/05-0427

Haponski AE, Foighil Ó, D, (2019) Phylogenomic analyses confirm a novel invasive North American Corbicula (Bivalvia: Cyrenidae) lineage. PeerJ 7:e7484. https://doi. org/10.7717/peerj.7484

Hu L-T, Bentler PM (1999) Cutoff criteria for fit indices in covariance structure analysis: conventional criteria versus new alternatives. Struct Equ Modeling 6:1-55. https://doi. org/10.1080/10705519909540118

Ilarri MI, Antunes C, Guilhermino L, Sousa R (2011) Massive mortality of the Asian clam Corbicula fluminea in a highly invaded area. Biol Invas 13:277-280. https://doi. org/10.1007/s10530-010-9833-5

James LA (2011) Contrasting geomorphic impacts of pre-and post-Columbian land-use changes in Anglo America. Phys Geogr 32:399-422. https://doi.org/10.2747/0272-3646. 32.5.399 
Johnson LE, Carlton JT (1996) Post-establishment spread in large-scale invasions: dispersal mechanisms of the zebra mussel Dreissena polymorpha. Ecology 77:1686-1690. https://doi.org/10.2307/2265774

Kędra M, Wiejaczka $Ł$ (2018) Climatic and dam-induced impacts on river water temperature: assessment and management implications. Sci Total Environ 626:1474-1483. https://doi.org/10.1016/j.scitotenv.2017.10.044

Lee T, Siripattrawan S, Ituarte CF, Foighil DO (2005) Invasion of the clonal clams: Corbicula lineages in the New World. Am Malacol Bull 20:113-122

Levine JM, D'Antonio CM (1999) Elton revisited: a review of evidence linking diversity and invasibility. Oikos 87:1526. https://doi.org/10.2307/3546992

Lopes-Lima M, Sousa R, Geist J et al (2017) Conservation status of freshwater mussels in Europe: state of the art and future challenges. Biol Rev 92:572-607. https://doi.org/ 10.1111/brv.12244

MacArthur R (1955) Fluctuations of animal populations, and a measure of community stability. Ecology 36:533-536. https://doi.org/10.2307/1929601

McDowell WG, McDowell WH, Byers JE (2017) Mass mortality of a dominant invasive species in response to an extreme climate event: Implications for ecosystem function. Limnol Oceanogr 62:177-188. https://doi.org/10. 1002/lno.10384

McMahon RF (1982) The occurrence and spread of the introduced Asiatic freshwater clam, Corbicula fluminea (Müller), in North America: 1924-1982. The Nautilus 96:134-141

McMahon RF (2002) Evolutionary and physiological adaptations of aquatic invasive animals: $r$ selection versus resistance. Can J Fish Aquat Sci 59:1235-1244. https://doi.org/ 10.1139/f02-105

Mills LS, Soulé ME, Doak DF (1993) The keystone-species concept in ecology and conservation. Bioscience 43:219224. https://doi.org/10.2307/1312122

Olsson K, Stenroth P, Nystrom P, Graneli W (2009) Invasions and niche width: does niche width of an introduced crayfish differ from a native crayfish? Freshw Biol 54:17311740. https://doi.org/10.1111/j.1365-2427.2009.02221.x

Pascal PY, Fleeger JW, Boschker HT, Mitwally HM, Johnson DS (2013) Response of the benthic food web to short-and long-term nutrient enrichment in saltmarsh mudflats. Mar Ecol Prog Ser 474:27-41. https://doi.org/10.3354/meps1 0090

Petter G, Weitere M, Richter O, Moenickes S (2014) Consequences of altered temperature and food conditions for individuals and populations: a dynamic energy budget analysis for Corbicula fluminea in the Rhine. Freshw Biol 59:832-846. https://doi.org/10.1111/FWB.12307

Pigneur LM, Marescaux J, Roland K, Etoundi E, Descy JP, Van Doninck K (2011) Phylogeny and androgenesis in the invasive Corbicula clams (Bivalvia, Corbiculidae) in Western Europe. BMC Evol Biol 11:1-16. https://doi.org/ 10.1186/1471-2148-11-147

Pimentel D, Zuniga R, Morrison D (2005) Update on the environmental and economic costs associated with alien-invasive species in the United States. Ecol Econ 52:273-288. https://doi.org/10.1016/j.ecolecon.2004.10.002
Poole KE, Downing JA (2004) Relationship of declining mussel biodiversity to stream-reach and watershed characteristics in an agricultural landscape. J N Am Benthol Soc 23:114-125

Power J, Schepers JS (1989) Nitrate contamination of groundwater in North America. Agric Ecosyst Environ 26:165187. https://doi.org/10.1016/0167-8809(89)90012-1

R Core Team (2018) R: a language and environment for statistical computing. R Foundation for Statistical Computing, Vienna, Austria. URL https://www.R-project.org

Robertson PA, Mill A, Novoa A, Jeschke JM, Essl F, Gallardo B, Geist J, Jarić I, Lambin X, Musseau C, Pergl J, Pyšek P, Rabitsch W, von Schmalensee M, Shirley M, Strayer DL, Stefansson RA, Smith K, Booy O (2020) A proposed unified framework to describe the management of biological invasions. Biol Invas 22:2633-2645. https://doi.org/ 10.1007/s10530-020-02298-2

Rosseel Y (2012) lavaan: an R package for structural equation modeling. J Stat Softw 48:1-36

Ruaro R, Mormul RP, Gubiani ÉA, Piana P, Cunico AM, Graça WJ (2018) Non-native fish species are related to the loss of ecological integrity in Neotropical streams: a multimetric approach. Hydrobiologia 817:413-430. https://doi.org/ 10.1007/s10750-018-3542-y

Sanchez GI, Hopper GW, Bucholz J, Atkinson CL (2021) Long-term monitoring reveals differential responses of mussel and host fish communities in a biodiversity hotspot. Diversity 13:122. https://doi.org/10.3390/d13030122

Satorra A, Bentler PM (2001) A scaled difference chi-square test statistic for moment structure analysis. Psychometrika 66:507-514. https://doi.org/10.1007/BF02296192

Simberloff D (2011) Elton Charles S. In: Simberloff D, Rejmanek M (eds) Encyclopedia of biological invasions. University of California Press, Berkeley, p 188

Sousa R, Rufino M, Gaspar M, Antunes C, Guilhermino L (2008) Abiotic impacts on spatial and temporal distribution of Corbicula fluminea (Müller, 1774) in the River Minho Estuary, Portugal. Aquat Conserv 18:98-110. https://doi.org/10.1002/aqc.838

Stansbery DH (1971) Rare and endangered freshwater mollusks in eastern United States. In: Jorgensen SE, Sharp RE (Eds.). In: Proceedings of a symposium on rare and endangered Mollusks (naiads) of the U.S. U.S. Fish Wildlife Service, Twin Cities, pp 5-18

Stelzer RS, Parr TB, Coulibaly M (2020) A ten year record of nitrate retention and solute trends in a Wisconsin sand plains stream: temporal variation at multiple scales. Biogeochemistry 147:125-147. https://doi.org/ 10.1007/s10533-019-00631-z

Stinchcomb GE, Messner TC, Driese SG, Nordt LC, Stewart RM (2011) Pre-colonial (AD 1100-1600) sedimentation related to prehistoric maize agriculture and climate change in eastern North America. Geology 39:363-366. https://doi.org/10.1130/G31596.1

Strayer DL (1999) Effects of alien species on freshwater mollusks in North America. J N Am Benthol Soc 18:74-98. https://doi.org/10.2307/1468010

Strayer DL, Caraco NF, Cole JJ, Findlay S, Pace ML (1999) Transformation of freshwater ecosystems by bivalves: a case study of zebra mussels in the Hudson River. Bioscience 49:19-27. https://doi.org/10.2307/1313490 
Troendle CA, Olsen WK (1994) Potential effects of timber harvest and water management on streamflow dynamics and sediment transport. In: Wallace CW, DeBano, LF (Eds.) Sustainable ecological systems: implementing an ecological approach to land management. Department of Agriculture, Forest Service, Rocky Mountain Forest and Range Experiment Station, Flagstaff, pp 34-41

USDA (2012) Available at https://www.ers.usda.gov/amberwaves $/ 2012 / \mathrm{march} /$ data-feature-how-is-land-used/. Accessed 23 March 2020

Vaughn CC, Spooner DE (2006) Scale-dependent associations between native freshwater mussels and invasive Corbicula. Hydrobiologia 568:331-339. https://doi.org/ 10.1007/s10750-006-0210-4

Vidal ML, Bassères A, Narbonne JF (2002) Influence of temperature, $\mathrm{pH}$, oxygenation, water-type and substrate on biomarker responses in the freshwater clam Corbicula fluminea (Müller). Comp Biochem Phys C 132:93-104. https://doi.org/10.1016/S1532-0456(02)00051-0

Villella RF, Smith DR (2005) Two-phase sampling to estimate river-wide populations of freshwater mussels. J N Am Benthol Soc 24:357-368. https://doi.org/10.1899/ 04-085.1

Vitousek PM (1990) Biological invasions and ecosystem processes: towards an integration of population biology and ecosystem studies. Oikos 57:7-13. https://doi.org/10. $2307 / 3565731$

Weitere M, Vohmann A, Schulz N, Linn C, Dietrich D, Arndt $\mathrm{H}$ (2009) Linking environmental warming to the fitness of the invasive clam Corbicula fluminea. Glob Chang Biol 15:2838-2851. https://doi.org/10.1111/j.13652486.2009.01925.x

Werner S, Rothhaupt KO (2008) Mass mortality of the invasive bivalve Corbicula fluminea induced by a severe low-water event and associated low water temperatures. In: Fischer P (ed) Wantzen KM, Rothhaupt K-O, Mörtl M, Cantonati M, G-Tóth L. Ecological Effects of Water-Level Fluctuations in Lakes. Springer, Dordrecht, pp 143-150

Williams JD, Warren ML Jr, Cummings KS, Harris JL, Neves RJ (1993) Conservation status of freshwater mussels of the United States and Canada. Fisheries 18:6-22. https://doi.org/10.1577/1548-8446(1993)018\%3c0006: CSOFMO \%3e2.0.CO;2

Zhang M, Liu N, Harper R, Li Q, Liu K, Wei X, Ninga D, Houa Y, Liu S (2017) A global review on hydrological responses to forest change across multiple spatial scales: Importance of scale, climate, forest type and hydrological regime. J Hydrol 546:44-59. https://doi.org/10.1016/j. jhydrol.2016.12.040

Publisher's Note Springer Nature remains neutral with regard to jurisdictional claims in published maps and institutional affiliations. 